\title{
The Effect of TNF- $\alpha$ on the Expression of MMP9 in Human Mesenchymal Bone Marrow-Derived Stem Cells
}

\author{
Khaled Sharifi ${ }^{1}$, Maryam Ayatollahi ${ }^{1}$, Ramin Yaghoubi ${ }^{1}$, Mohmmad Hossain Sanati ${ }^{2}$, Afsune Afshari ${ }^{1}$, Ali \\ Hatamian Fard ${ }^{1}$ \\ ${ }^{1}$ Transplant Research Center University of Medical Science Shiraz, Shiraz, Iran \\ ${ }^{2}$ National Institute of Genetic Engineering and Biotechnology, Tehran, Iran \\ Correspondence: Khaled Sharifi, transplant research center university of medical science shiraz. Email address: \\ god.sharifi1390@gmail.com
}

Received: May 7, 2020

Accepted: July 17, 2020

Online Published: November 30, 2020

doi:10.5539/jmbr.v10n1p138

URL: https://doi.org/10.5539/jmbr.v10n1p138

\begin{abstract}
Matrix metalloproteinase 9 (MMP9) as the enzyme of adult stem cells secreted from damage cells. In spite of low level of MMP9 enzyme in the mesenchymal stem cells, many inflammatory cytokines stimulation such as TNF- $\alpha$ could increase MMP9 level in cells.

Current study evaluated the expression of the MMP9 enzyme under the influence of TNF- $\alpha$ in human bone marrow mesenchymal stem cells.

The human bone marrow mesenchymal stem cells were classified into control and experimental groups. In the experimental groups, various concentrations of the TNF- $\alpha(1 \mathrm{ng} / \mathrm{ml}$ and $10 \mathrm{ng} / \mathrm{ml})$ were administrated in different times (10 and 24 hours), whereas the control group was not treated with TNF- $\alpha$. MMP9 gene expression was evaluated by Real-Time PCR. TNF- $\alpha$ administration in $1 \mathrm{ng} / \mathrm{ml}$ and $10 \mathrm{ng} / \mathrm{ml}$ dosage for 10 hours, induced the expression of MMP9 1468.3 and 1782.8 times more than the control group, respectively.

After $24 \mathrm{~h}$, in comparison between $1 \mathrm{ng} / \mathrm{ml}$ and $10 \mathrm{ng} / \mathrm{ml}$ with control groups, MMP9 expression were 442.64 and 1184.4 times more than control group, respectively.

In conclusion, the expression rate of the MMP9 gene in bone marrow mesenchymal stem cells might be effected by dosage and time of exposure to TNF- $\alpha$. Furthermore, the time of exposure might have the prominent role in alteration of MMP9 gene expression induction in the mesenchymal stem cells.
\end{abstract}

Keywords: Bone Marrow, Mesenchymal Stem Cell, MMP9 Enzyme, TNF- $\alpha$, Cell Migration

\section{Introduction}

Mesenchymal stem cells (MSCs) participate to repair of their originated tissues such as bone, cartilage, muscle, tendon, and fat. Moreover, these are supportive cells for the hematopoietic cells production (Friedenstein et al., 1966). Typical mesenchymal stem cells were specialized to differentiated cells in the same texture of originated tissues when abnormal tissue proliferation occurs, as a result, they called them adult stem cells (Ullah et al., 2015).

According to International Society of Cell Therapy (ISCT) definition Human MSCs attache to the bottom of plastic culture dishes in the normal culture conditions. They are negative for the expression of the surface markers CD105, CD73 and CD90, hematopoietic markers CD45, CD34 and other markers such as CD19, CD79, CD11b, CD14 as well as HLA-DR; and should have been able to differentiate into adipocytes, cartilage and bone in vitro (Keating, 2006).

Many studies have shown that MSCs are able to escape from immune system and inhibit the immune response which have key role in transplantation and cell therapy (Zhao et al., 2011). MSCs have been used for tissue regeneration in several clinical studies especially in wound healing (Perry et al., 2008). Also, Human and mouse MSCs have been used in the mouse models of spinal cord injury healing as well as damaged heart tissue recovery (Rojas et al., 2005).

Matrix metalloproteinases (MMPs), as a calcium-dependent zinc-containing endopeptidases, express in the most damaged tissues such as cardiovascular and liver injury. The activity of these enzymes is regulated by tissue inhibitors. Changes in the expression levels of these enzymes have been reported in liver disease and 
development as well as damaged body tissue treatment such as liver transplantation or stem cell transplantation. These enzymes digest many components of the extracellular matrix (ECM) and basement membrane structure, and their role is significant in physiological and pathological processes (Duarte et al., 2015).

MMPs have been reported to be either proenzyme or enzymes in biological samples. The activity of this protein is required for the precise regulation and control of cells including keratinocytes, fibroblasts, endothelial cells, macrophages, neutrophils, mast cells, acidophilic and CD $34^{+}$bone marrow, and umbilical cord. MMPs protein activity and degeneration must be controlled by the specific inhibitors. Inhibitors of this enzyme family (TIMPs) have a high concentration in the serum. (Behrendtsen \& Werb, 1997).

Matrix metalloproteinase 9 (MMP9) gene family, the enzyme of adult stem cells in all tissues (especially in bone marrow, umbilical cord, and liver), is secreted from damaged cells. Kuppfer cells are important group of cells in the liver with macrophage-like behavior. Expression of MMP9 enzyme is increased with enhanced activity of Kuppfer cells. Progelatinaze B is activated by plasmin and estomelesine through protease activity, leading to a $92 \mathrm{kDa}$ protein production. One of the most important members of Progelatinaze B gene family, gelatinase, is the major basement membrane composition in human cells. Gelatinase is the only member of this family with capability of binding to fibronectin and digesting collagen. Human MMP-9 gene is located on chromosome 20q and contains 13 exons which is a polymorphism $\mathrm{C} / \mathrm{T}$ in the promoter region and leading to changes in the expression of this gene (Luo et al., 2004).

TNF- $\alpha$ belongs to the superfamily of TNF which comprises at least 19 members. TNF- $\alpha$ is produced by activated mononuclear phagocytic cells, antigen-stimulated T cells, NK, mast cells, and fibroblasts. TNF receptors are TNF-RI and TNF-RII that are found in most cells. TNF receptor binding strength is weaker than the other cytokines. TNF is a member of large proteins family involved in immune response and inflammation. Cytokines bind to the cytoplasmic domain of the TNF receptors induced activation of the transcription factors particularly nuclear factor $\mathrm{\kappa B}(\mathrm{NF}-\mathrm{\kappa B})$ and activation protein (AP-1) which leading to caspase activation, apoptosis, and cell death (Hong et al., 2013).

The main physiological action of TNF is recruiting the monocytes and neutrophils to the site of infection. On the other hand, TNF affects the vascular endothelial cell adhesion molecules. TNF also stimulates the endothelial cells and macrophages to secrete the enzymes and cause leukocyte chemotaxis (Hong et al., 2013).

In the current study, we identified human umbilical cord mesenchymal stem cells (hUC-MSCs) by flow cytometry assay and induced differentiation assay to investigate whether the inflammatory environment could affect MSCs proliferation, migration and cytokines secretion. Also MSCs stimulation were examined by both TNF- $\alpha(20 \mathrm{ng} / \mathrm{ml})$ and IFN- $\gamma(50 \mathrm{ng} / \mathrm{ml})$ as well as cell viability by MTT assay, migration by trans well assay, and cytokines expression level by real-time PCR analysis.

\section{Material and Methods}

\subsection{Isolation and Culture of Human MSCs}

Human MSCs were obtained from 5-ml iliac crest aspirates of about 15 normal donors within the age range of 20-50 years who underwent bone marrow collection for a related patient after obtaining approval of the ethics committee. The code of ethics was taken from Shiraz University of Medical Sciences. Written informed consent was collected for clinical data collection and paraclinical examination. Each sample of aspirate was diluted 1:1 with Dulbecco's modified Eagle's medium (DMEM)-low glucose (1,000 mg/l glucose) (Invitrogen, Merelbeke, Belgium) and layered over about $5 \mathrm{ml}$ of ficoll (Lymphoprep; Oslo, Norway). The isolation method was based on a previously reported method with slight modifications (Ayatollahi et al., 2011).briefly. after centrifugation harvested sample at $939 \mathrm{~g}$ for $20 \mathrm{~min}$, the mononuclear cell layer was removed from the interface. The cells were suspended in DMEM and centrifuged again at $338 \mathrm{~g}$ for $15 \mathrm{~min}$. Then, centrifuged cells were suspended in basal DMEM medium containing 10\% fetal calf serum (Invitrogen, Merelbeke, Belgium), 1\% penicillin (Invitrogen, Merelbeke, Belgium), 1\% streptomycin (Invitrogen, Merelbeke, Belgium), and $2 \mathrm{mM}$ glutamine (Invitrogen, Merelbeke, Belgium). The cells were seeded at a density of $80.000 / \mathrm{cm}^{2}$ in $25 \mathrm{~cm}^{2}$ T-flasks and maintained at $37^{\circ} \mathrm{C}$ in an atmosphere of $5 \% \mathrm{CO} 2$. After 4 days, the non-adherent cells were removed and the media changed every 3 days. In order to expand the MSCs cells, the adhered monolayer was detached with trypsin-EDTA (Invitrogen, Merelbeke, Belgium) for $5 \mathrm{~min}$ at $37^{\circ} \mathrm{C}$, after 14 days for the first passage as well as every $4-5$ days for successive passages sample. During in vitro passaging, the cells were seeded at a density of $5-10 \times 10^{3}$ cells $/ \mathrm{cm}^{2}$ and expanded for several passages until they no longer reached confluence.

\subsection{Characterization of MSCs}

At each stage of passage, the cells were counted and analyzed for viability by trypan blue staining analysis. 
Cultured MSCs have been analyzed both morphologically and surface markers examination. Functional ability of differentiation into osteocyte and adipocyte were achieved in response to specific culture conditions. Each experiment described here was replicated three times.

\subsection{Flow Cytometric Analysis}
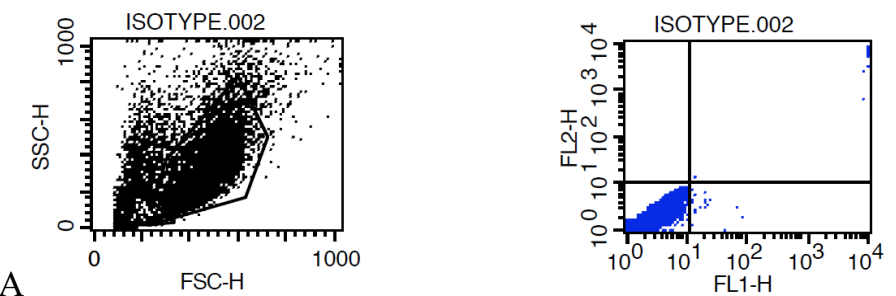

\section{Quadrant Statistics}

\begin{tabular}{|c|c|c|c|}
\hline \multirow{2}{*}{\multicolumn{4}{|c|}{ Sample ID: ISOTYPE }} \\
\hline & & & \\
\hline \multicolumn{4}{|c|}{ Gate: G6 } \\
\hline \multicolumn{4}{|c|}{ Total Events: 10000} \\
\hline \multicolumn{4}{|c|}{ Y Parameter: FL2-H (Log) } \\
\hline Quad & Events & $\%$ Gated & $\%$ Total \\
\hline$\overline{\mathrm{UL}}$ & 0 & 0.00 & 0.00 \\
\hline UR & 14 & 0.20 & 0.14 \\
\hline LL & 7110 & 99.48 & 71.10 \\
\hline LR & 23 & 0.32 & 0.23 \\
\hline
\end{tabular}

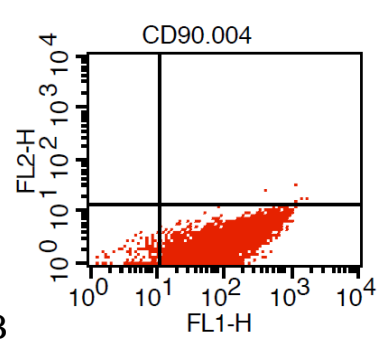

\begin{tabular}{|c|c|c|c|c|}
\hline \multicolumn{5}{|c|}{ 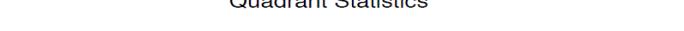 } \\
\hline \multicolumn{4}{|c|}{ File: CD90.004 } & Log Data Units: Linear Values \\
\hline \multicolumn{4}{|c|}{ Sample ID: CD90 } & Patient ID: \\
\hline \multicolumn{4}{|c|}{ Gate: G1 } & Gated Events: 7073 \\
\hline \multicolumn{4}{|c|}{ Total Events: 10000} & X Parameter: FL1-H (Log) \\
\hline \multicolumn{4}{|c|}{ Y Parameter: FL2-H (Log) } & Quad Location: 11, 14 \\
\hline Quad & Events & $\%$ Gated & $\%$ Total & \\
\hline UL & 0 & 0.00 & 0.00 & \\
\hline UR & 7 & 0.10 & 0.07 & \\
\hline LL & 158 & 2.23 & 1.58 & \\
\hline LR & 6908 & 97.67 & 69.08 & \\
\hline
\end{tabular}

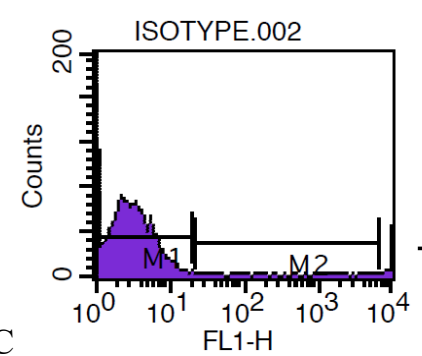

\begin{tabular}{|c|c|c|c|c|c|}
\hline \multicolumn{6}{|c|}{ Histogram Statistics } \\
\hline \multicolumn{3}{|c|}{ File: ISOTYPE.002 } & \multicolumn{3}{|c|}{ Log Data Units: Linear Values } \\
\hline \multicolumn{3}{|c|}{ Sample ID: ISOTYPE } & \multicolumn{3}{|c|}{ Patient ID: } \\
\hline \multicolumn{3}{|c|}{ Gate: No Gate } & \multicolumn{3}{|c|}{ Gated Events: 10000} \\
\hline \multicolumn{3}{|c|}{ Total Events: 10000} & \multicolumn{3}{|c|}{ X Parameter: FL1-H (Log) } \\
\hline Marker & Events & $\%$ Gated & $\%$ Total & Mean & Peak Ch \\
\hline All & 10000 & 100.00 & 100.00 & 163.74 & 1 \\
\hline M1 & 9740 & 97.40 & 97.40 & 3.30 & 1 \\
\hline M2 & 100 & 1.00 & 1.00 & 1919.57 & 21 \\
\hline
\end{tabular}

Histogram Statistics

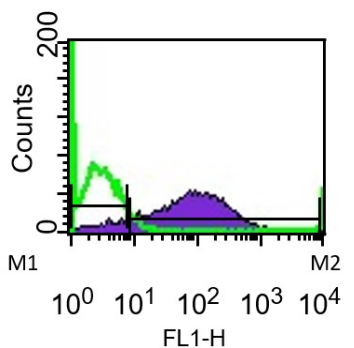

File: CD90.004 Log Data Units: Linear Values Sample ID: CD90 Patient ID:

Gate: No Gate

Gated Events: 10000

Total Events: 10000

X Parameter: FL1-H (Log)

Marker Events \% Gated \% Total Mean Peak Ch

\begin{tabular}{rrrrrr}
\hline All & 10000 & 100.00 & 100.00 & 133.58 & 73 \\
M1 & 670 & 6.70 & 6.70 & 4.39 & 1 \\
M2 & 9255 & 92.55 & 92.55 & 142.88 & 73
\end{tabular}


Figures 1. Use Two types antibody on hMSC, graph A and histogram C ellustrate no antigen receptores for isotype 002 on hMSC but graph B and histogram D ellustrate exist antigen receptores for CD90 on hMSC

The identification of adherent cells was performed by flow cytometric analysis. At the third passage, the cells were detached from the culture flasks with trypsin-EDTA and counted. About $1 \times 10^{6}$ of cells were incubated on ice for $30 \mathrm{~min}$ with goat serum, re-suspended in phosphate-buffered saline (PBS), and pelleted by centrifugation for $4 \mathrm{~min}$ at $2100 \mathrm{rpm}$. Subsequently, the cells were stained for $30 \mathrm{~min}$ at $4^{\circ} \mathrm{C}$ with a fluorescent isothiocyanate (FITC)-coupled or phycoerythrin (PE)-conjugated isotype 002 (negative control), HLADR, CD45, CD90, CD80, and CD40. The labeled cells were thoroughly washed with PBS and analyzed on a flow cytometer system (FACS Calibur Becton, Dickinson, USA), by WinMidi software (Scripps Research Institute; San Diego, USA). The percentage of positive cells was calculated by the cells stained with Ig FITC/PE as a negative control.

\subsection{Experimental Groups}

The MSCs of the six passages were trypsinized with $0.25 \%$ trypsin-EDTA and the cell suspension was centrifuged at $1200 \times \mathrm{g}$ for $5 \mathrm{~min}$. The cells were then treated with TNF- $\alpha$ at different concentrations and incubated at different times. Differences in the expression levels of MMP9 were compared between TNF- $\alpha$-treated and untreated MSCs. Also, differences in the expression levels of MMP9 were compared in different concentrations and times of the treatment by TNF- $\alpha$. The cells were divided into the following groups: 1) without TNF- $\alpha$ treatment; 2) stimulated for $10 \mathrm{hr}$ with $1 \mathrm{ng} / \mathrm{ml} \mathrm{TNF}-\alpha$; 3) stimulated for $24 \mathrm{hr}$ with $1 \mathrm{ng} / \mathrm{ml} \mathrm{TNF}-\alpha$; 4) stimulated for $10 \mathrm{hr}$ with $10 \mathrm{ng} / \mathrm{ml} \mathrm{TNF}-\alpha$; and 5) stimulated for $24 \mathrm{hr}$ with $10 \mathrm{ng} / \mathrm{ml} \mathrm{TNF}-\alpha$.

\subsection{RNA Extraction}

Total RNA was extracted from TNF- $\alpha$ treated and untreated MSCs groups by RNX Plus solution kit (Cinna Gene- Iran) with following protocol: $1000 \mu \mathrm{l}$ cultured MSCs were centrifuged at $12000 \mathrm{rpm}$ for $5 \mathrm{~min}$. The

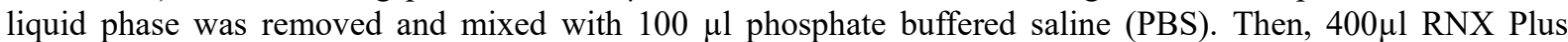
solution and $200 \mu \mathrm{l}$ cold chloroform were added and centrifuged at $13500 \mathrm{rpm}$ for $20 \mathrm{~min}$ in $4^{\circ} \mathrm{C}$ condition which kept overnight at $-20^{\circ} \mathrm{C}$. Finally, the pellet was washed twice with ethanol $75 \%$ and dissolved in the $25 \mu \mathrm{DEPC}$ water.

\section{6 cDNA Synthesis}

cDNA was synthesized by in-house optimized protocol in total volume of $23 \mu \mathrm{l}$. first of all, $1 \mu \mathrm{l}(0.2 \mu \mathrm{g} / \mu \mathrm{l}) \mathrm{of}$ Random hexamer (Cinna Gene-Iran), $2 \mu \mathrm{l}$ (200 U/ $\mu \mathrm{l}$ ) of M-MuLv reverse transcriptase (ViVantis-Indonesia), $2 \mu 1$ (10x) of reverse transcriptase buffer, $2 \mu \mathrm{l}(10 \mathrm{mMol})$ of dNTP (Cinna Gene-Iran), $1.3 \mu \mathrm{l}(40 \mathrm{U} / \mu \mathrm{l}) \mathrm{RNase}$ inhibitor (ViVantis-Indonesia), and $14.7 \mu 1 \mathrm{DEPC}$ water. Finally, cDNA was synthesized in $42^{\circ} \mathrm{C}$ for 90 minutes followed by $85^{\circ} \mathrm{C}$ for 5 minutes.

\subsection{Real-Time Polymerase Chain Reaction}

The relative quantification of MMP9 in comparison with $\beta$-actin mRNA expression was performed after the designation of the specific primers for both MMP9 and $\beta$-actin gene transcripts. The MMP9 and $\beta$-actin primer sequences were as follows respectively:

Forward primer: 5'-GGACAAGCTCTTCGGCTTCT-3 ’ Reverse primer: 5 `-

TCGCTGGTACAGGTCGAGTA-3 `and Forward primer: 5 `-

GGGCGGCACCACCATGATCC-3`; Reverse primer: $5^{`}$ -

\section{GACGATGGAGGGGCCCGACT-3’.}

$$
\text { اشـاره نشده است؟ مجر ا در اينجا به }
$$

Table 1. Real-time PCR reactions for MMP9 and $\beta$-actin genes

\begin{tabular}{lll}
\hline Component & Amount $(\boldsymbol{\mu l})$ & Concentration \\
\hline SYBR premix Ex Taq II & 10 & $1 \mathrm{x}$ \\
Dye & 0.4 & $1 \mathrm{x}$ \\
Forward primer & 0.4 & $5 \mathrm{pM}$ \\
Reverse primer & 0.4 & $5 \mathrm{pM}$ \\
DEPC water & 6.8 & - \\
cDNA & 2 & $100 \mathrm{ng}$ \\
Total & 20 & - \\
\hline
\end{tabular}


Table 2. Real-time PCR programs for MMP9 and $\beta$-actin genes

\begin{tabular}{|c|c|c|c|c|}
\hline Gene & Step & Temperature $\left({ }^{\circ} \mathrm{C}\right)$ & Time & Cycle \\
\hline \multirow{5}{*}{ MMP9 } & Denaturation & 95 & $2 \min$ & 1 \\
\hline & Denaturation & 95 & $30 \mathrm{~s}$ & \\
\hline & Annealing & 57.5 & $20 \mathrm{~s}$ & 40 \\
\hline & Extension & 72 & $30 \mathrm{~s}$ & \\
\hline & Final extension & 72 & $5 \mathrm{~min}$ & 1 \\
\hline \multirow{5}{*}{$\beta$-actin } & Denaturation & 95 & $2 \min$ & 1 \\
\hline & Denaturation & 95 & $30 \mathrm{~s}$ & \\
\hline & Annealing & 64 & $20 \mathrm{~s}$ & 40 \\
\hline & Extension & 72 & $30 \mathrm{~s}$ & \\
\hline & Final extension & 72 & $5 \mathrm{~min}$ & 1 \\
\hline
\end{tabular}

Upon making the PCR reaction mixes, the expression analysis was performed by the real-time PCR thermocycler (Step one plus Applied Biosystems-U.S.A) (Table 1 and 2). The fold change of relative mRNA expression was determined by using Livak method $\left(2^{-\Delta \Delta \mathrm{Ct}}\right)$.

\section{Results}

\subsection{Isolation and Expansion of Human MSCs}

Adherent cells were observed in all samples after 3 days of culture and 15 days later, adherent monolayer was achieved (Figure 2A). The rapid expansion of the MSCs in the culture might be related to the presence of single-cell-derived colonies composed of a few fibroblast-like cells (Figure 2B). Bone marrow cells rapidly generated a confluent layer of cells with an elongated, fibroblastic shape. These cells contained two types: a type of cells with large and flat morphology, and a type of smaller spindle-shaped cells (Figure 2C). The cells were increased in size and showed a polygonal morphology with evident filaments in the cytoplasm, especially when early passage cells were compared with late passage cells. MSCs isolated from healthy donors were expanded for up to 10 passages.

\subsection{Viability Evaluation}

At each passage, the cells were counted and analyzed for viability by trypan blue staining analysis, showing a viability of $98-100 \%$ in the samples.

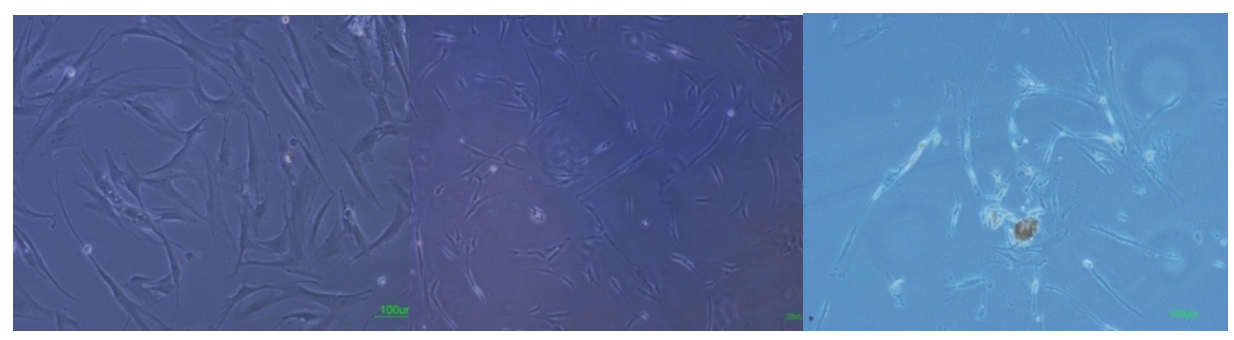

A

B

$\mathrm{C}$

Figure 2. Isolation and culture of human bone marrow derived MSCs

A) Adherent monolayer was achieved in the following 6-7 days;

B) The presence of single cell-derived colonies composed of a few fibroblast-like cells;

C) As the culture proceeded, the cells were both of small spindle, and wide-shaped morphology. Scale bar for the Figures A-C is $100 \mathrm{um}$.

\subsection{MMP9 Expression}

The expression level of MMP9 gene in the untreated MSCs was lower than treatment groups (Table 3). The expression level of MMP9 gene was compared for various treatment conditions with different times and concentrations that was highly increased in the two treatments including $1 \mathrm{ng} / \mathrm{ml}\left(2^{-\Delta \Delta \mathrm{Ct}}=1468.3\right)$ and $10 \mathrm{ng} / \mathrm{ml}$ $\left(2^{-\Delta \Delta \mathrm{Ct}}=1782.8\right) \mathrm{TNF}-\alpha$ for $10 \mathrm{~h}$ (Table 3 and Figure 2). However, the highest level of MMP9 gene expression was found upon treatment with $10 \mathrm{ng} / \mathrm{ml} \mathrm{TNF- \alpha}$ for $10 \mathrm{~h}\left(2^{-\Delta \Delta \mathrm{Ct}}=1782.8\right)$ (Table 3 and Figure 3 ). 
Table 3. Gene expression level of MMP9 and $\beta$-actin in MSCs after treatment with TNF- $\alpha$

\begin{tabular}{llllll}
\hline Conditions of treatment with TNF- $\boldsymbol{\alpha}$ & Ct MMP9 & Ct $\boldsymbol{\beta}$-actin & $\Delta \mathbf{C t}$ & $\Delta \Delta \mathbf{C t}$ & $\mathbf{2}^{-\Delta \Delta \mathbf{C t}}$ \\
\hline $1 \mathrm{ng} / \mathrm{ml}-10$ hours & 17.28 & 17.69 & -0.41 & -52.10 & 1468.3 \\
$1 \mathrm{ng} / \mathrm{ml}-24$ hours & 14.89 & 13.57 & 1.32 & -8.79 & 442.64 \\
$10 \mathrm{ng} / \mathrm{ml}-10$ hours & 19.78 & 20.47 & -0.69 & -10.8 & 1782.8 \\
$10 \mathrm{ng} / \mathrm{ml}-24$ hours & 18.14 & 18.97 & -0.83 & -10.21 & 1184.4 \\
Negative Control (Untreated) & 32.46 & 22.35 & 10.11 & - & - \\
\hline
\end{tabular}

A) Comparison of TNF- $\alpha$ concentration on MMP9 expression

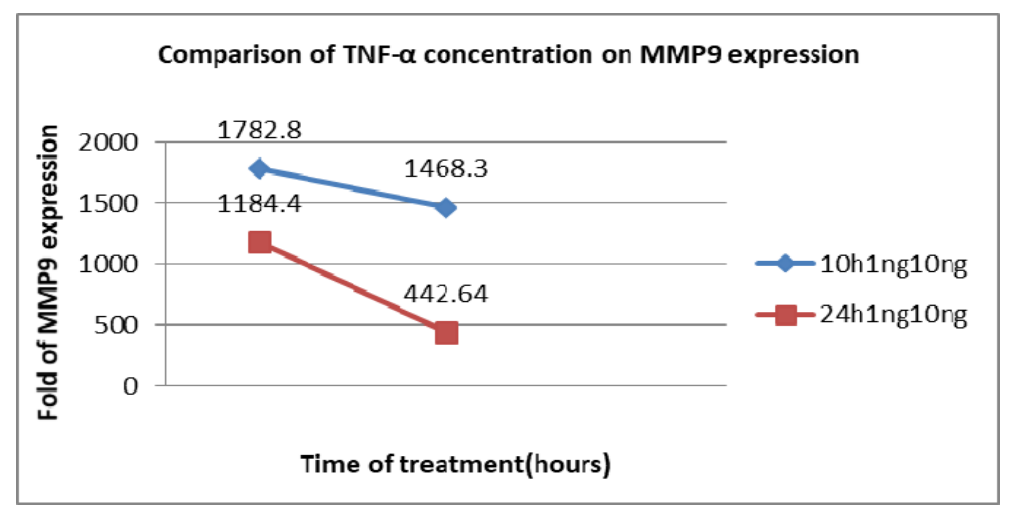

B) MMP9 expression in treated and untreated hBMSCs

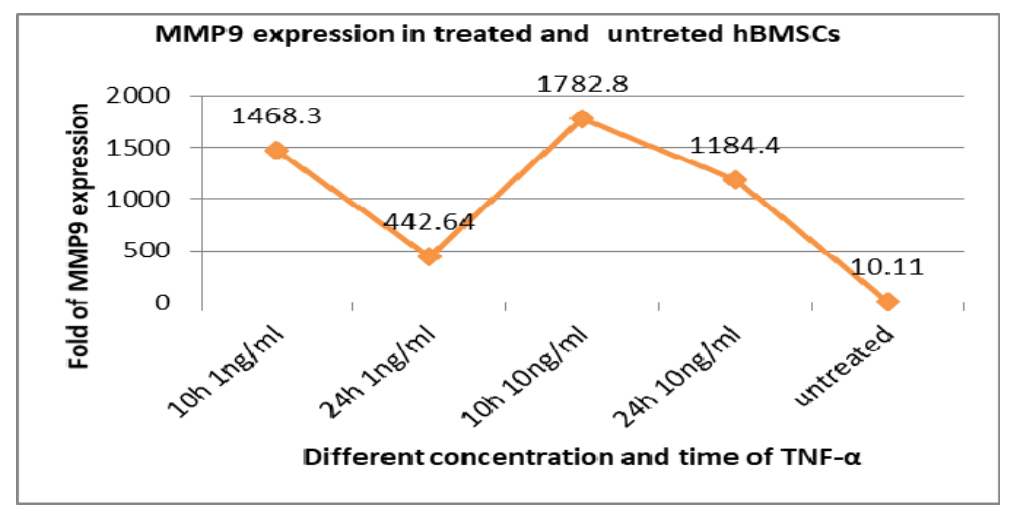

C) Histogram chart effect of concentration TNF- $\alpha$ on expression mmp9 in hBMSCs

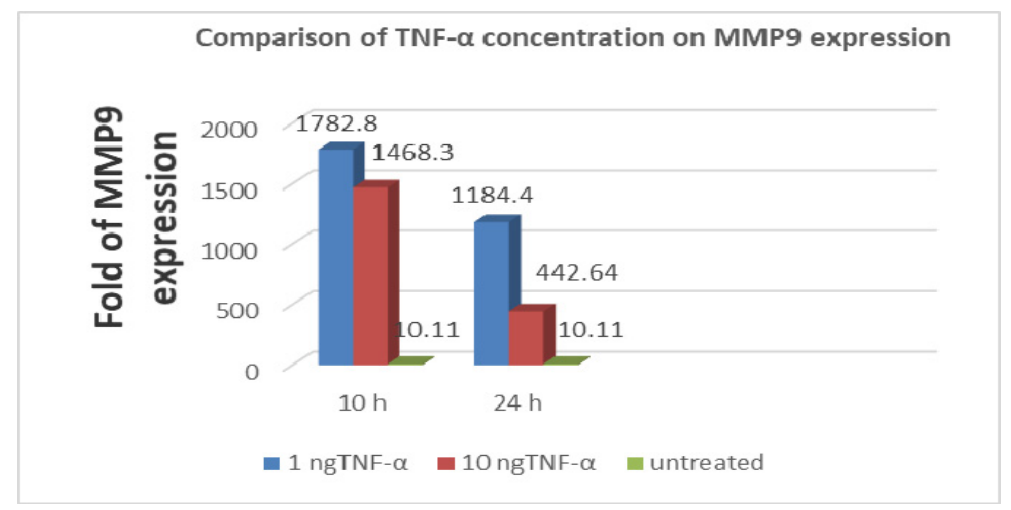

Figure 3. Comparison of TNF- $\alpha$ concentration on MMP9 gene expression in the treated and untreated MSCs 


\section{Discussion and Conclusion}

Mesenchymal stem cells are nonhematopoietic stem cells with multi-proliferative and multi-differentiative potentials. The ability of MSCs to modulate the immune responses and migration to the site of inflammation makes these cells a promising source of cells for cell-based therapeutic strategies (Tsai et al., 2011). Chemokine receptors, ligands, and adhesion molecules play key roles in tissue-specific homing of the leukocytes and have also been implicated in trafficking of hematopoietic precursors into the tissues. The migration of MSCs to the sites of injury or inflammation is also mediated by chemotactic factors produced by the immune cells. It has been demonstrated that human MSCs show significant chemotaxis responses to several factors, including PDGF, VEGF, IGF-1, IL-8, bone morphogenetic protein (BMP)-4 and BMP-7 (Yorsangsukkamol et al., 2011; Kollet et al., 2003). The mechanism of MSCs migration and homing has not been fully understood. Although it seems that homing in MSCs occurs by tethering, rolling and endothelial transmigration similar to the leukocytes; however, they differ in the types of molecules involved in the migration process. For example, MSCs do not utilize E or P-selectin as a tethering mechanism since they do not express the fucosyltransferase IV or VII, and use other adhesion molecules such as CD44, VLA-4 and VCAM (Yorsangsukkamol et al., 2011). MSCs are also large cells, so they can hold up on capillary beds which allow them to transmigrate across the endothelium in response to chemokine gradient (Ullah et al., 2015).

In this study, we analyzed different gene expression patterns of chemokine receptor MMP9 on MSCs which have a critical role in migration and engraftment. It was shown that human bone marrow MSCs expressed low level of MMP9. Our observation was confirmed by other studies such as that of Wynn et al.; they reported that a small portion of MSCs expressed MMP9 which contributed to their migration in vitro. They showed that less than 1\% of human MSCs express CXCR4 (Wynn et al., 2004). Ahmadian Kia et al. observed low or no detectable mRNA expression of MMP9 in the bone marrow MSCs, whereas Sordi et al. demonstrated that $26 \%$ of human bone marrow MSCs express CXCR4 (Ahmadian Kia et al., 2011; Sordi et al., 2005). There are controversial reports about expressing chemokine receptors on MSCs (Macfarlan et al., 2012; Nakagawa \& Yamanaka, 2010; Meriane et al., 2006).

Considering the important role of the couple of ligand-receptor SDF-1/ MMP9 in cell migration and cell engraftment, overexpression of chemokine receptor MMP9 on MSCs increases the ability of migration and engraftment for clinical application of these cells and this can be one of the strategies for enhancing the potential of MSCs in cell-based therapies. On the other hand, there are various inflammatory cytokines and chemokines at the injured sites that can lead to movement of MSCs to the injured and inflamed tissues (Meriane et al., 2006). These cytokines can regulate the expression of genes in various cells depending on the cell type and differentiation stage (Nombela-Arrieta et al., 2011).

TNF- $\alpha$ is a pro-inflammatory cytokine that has been shown to affect the gene expression in cells and can influence the expression of molecules involved in the migration process (Meriane et al., 2006; Tsai et al., 2011). Recently, it has been demonstrated that MMP9 expression increase in gastric cancer cells is induced by TNF- $\alpha$ (Zhao et al., 2010). Croitoru-Lamoury et al. demonstrated that IFN- $\gamma$ and IFN-1 $\beta$ up-regulated the chemokines and chemokine receptors in human MSCs (Croitoru-Lamoury et al., 2007). Esteve et al. observed that MMP9 expression in treated human astroglioma cells was enhanced by TNF- $\alpha$ and IL-1 $\beta$ (Esteve et al., 2002). However, it has also been reported that TNF- $\alpha$ reduces chemokine receptor expression in some types of cells. Tikhonov et $a l$. have found downregulation of MMP2 expression by TNF- $\alpha$ in polymorphonuclear leukocytes (Tikhonov et al., 2001).

Our data suggest that TNF- $\alpha$ can up-regulate the MMP9 expression in human bone marrow MSCs in a time and concentration-dependent manner. We observed that the highest level of MMP9 gene expression was treated with $10 \mathrm{ng} / \mathrm{ml} \mathrm{TNF-} \alpha$ for 10 hours. We revealed that the optimum time of TNF- $\alpha-$ treatment for enhancing MMP9 expression was 10 hours.

Previously, Kulbe et al. treated the ovarian cancer cells with 1, 10 and $100 \mathrm{ng} / \mathrm{ml} \mathrm{TNF- \alpha}$ in different incubation times (Kulbe et al., 2007). They have indicated that the most rate of MMP9 expression level occurred in 10 $\mathrm{ng} / \mathrm{ml}$ TNF- $\alpha$ between 6 to 24 hours. They also have demonstrated that there is a relationship between TNF- $\alpha /$ NF- $-\mathrm{BB}$ and MMP9 expression (Cheng et al., 2008). Effect of TNF- $\alpha$ on MMP-9 expression in HT1376 cells, the experiment showed the expression of mmp9 in $100 \mathrm{ng} / \mathrm{ml}$ and time $24 \mathrm{~h}$ of TNF- $\alpha$ (Se-Jung Lee et al., 2007).

TNF- $\alpha$ - induced production of matrix metalloproteinase- 9 by human bronchial epithelial cells. After stimulation with TNF-a $(10 \mathrm{ng} / \mathrm{ml})$, the level of matrix metalloproteinase- 9 mRNA was increased in a time-dependent manner and the expression peaked at $24 \mathrm{~h}$ (Hozumi et al., 2001). To determine the effect of TNF- $\alpha$ on MMP-9 
expression, MC3T3-E1 cells were incubated with various concentrations of TNF- $\alpha$ for the indicated time intervals. The experiment also showed expression of mmp9 in $30 \mathrm{ng} / \mathrm{ml}$ and time $48 \mathrm{~h}$ of TNF- $\alpha$ (Chia-Lan Tsai et al., 2014).

The results of current study suggested that in vitro control of environmental factors both in the concentration and time level may be important in the stem cell migration capacity and perhaps it is crucial in stem cell transplantation therapies.

\section{Acknowledgements}

The authors would like to thank the Transplant Research Center personnel at Shiraz University of Medical Sciences.

\section{Conflict of interests}

The authors declare that there is no conflict of interests regarding the publication of this paper.

\section{References}

Ahmadian Kia, N., Bahrami, A. R., Ebrahimi, M., Matin, M. M., Neshati, Z., Almohaddesin, M. R., Aghdami, N., \& Bidkhori, H. R. (2011). Comparative analysis of chemokine receptor's expression in mesenchymal stem cells derived from human bone marrow and adipose tissue. $J$ Mol Neurosci, 44, 178-85. https://doi.org/10.1007/s12031-010-9446-6

Ayatollahi, M., Soleimani, M., Geramizadeh, B., \& Imanieh, M. H. (2011). Insulin-like growth factor 1 (IGF-I) improves hepatic differentiation of human bone marrow-derived mesenchymal stem cells. Cell Biol Int, 35, 1169-76. https://doi.org/10.1042/CBI20110016

Behrendtsen, O., \& Werb, Z. (1997). Metalloproteinases regulate parietal endoderm differentiating and migrating in cultured mouse embryos. Developmental Dynamics, 208, 255-265. https://doi.org/10.1002/(SICI)1097-0177(199702)208:2<255::AID-AJA12>3.0.CO;2-2

Cheng, Z., Ou, L., Zhou, X., Li, F., Jia, X., Zhang, Y., Liu, X., Li, Y., Ward, C. A., Melo, L. G., \& Kong, D. (2008). Targeted migration of mesenchymal stem cells modified with CXCR4 gene to infarcted myocardium improves cardiac performance. Mol Ther, 16, 571-9. https://doi.org/10.1038/sj.mt.6300374

Croitoru-Lamoury, J., Lamoury, F. M., Zaunders, J. J., Veas, L. A., \& Brew, B. J. (2007). Human mesenchymal stem cells constitutively express chemokines and chemokine receptors that can be upregulated by cytokines, IFN-beta, and Copaxone. J Interferon Cytokine Res, 27, 53-64. https://doi.org/10.1089/jir.2006.0037

Duarte, S., Baber, J., Fujii, T., \& Coito, A. J. (2015). Matrix metalloproteinases in liver injury, repair and fibrosis. Matrix Biol, 44-46, 147-56. https://doi.org/10.1016/j.matbio.2015.01.004

Esteve, P. O., Robledo, O., Potworowski, E. F., \& ST-Pierre, Y. (2002). Induced expression of MMP-9 in C6 glioma cells is inhibited by PDGF via a PI 3-kinase-dependent pathway. Biochem Biophys Res Commun, 296, 864-9. https://doi.org/10.1016/S0006-291X(02)02008-9

Friedenstein, A. J., Piatetzky, S., II \& Petrakova, K. V. (1966). Osteogenesis in transplants of bone marrow cells. J Embryol Exp Morphol, 16, 381-90.

Hong, S., Li, R., Xu, Q., Secombes, C. J., \& Wang, T. (2013). Two types of TNF-alpha exist in teleost fish: phylogeny, expression, and bioactivity analysis of type-II TNF-alpha3 in rainbow trout Oncorhynchus mykiss. J Immunol, 191, 5959-72. https://doi.org/10.4049/jimmunol.1301584

Kaneko, M., Tomita, T., Nakase, T., Ohsawa, Y., Seki, H., Takeuchi, E., Takano, H., Shi, K., Takahi, K., \& Kominami, E. (2001). Expression of proteinases and inflammatory cytokines in subchondral bone regions in the destructive joint of rheumatoid arthritis. Rheumatology (Oxford), 40, 247-255. https://doi.org/10.1093/rheumatology/40.3.247

Keating, A. (2006). Mesenchymal stromal cells. Curr Opin Hematol, 13, 419-25. https://doi.org/10.1097/01.moh.0000245697.54887.6f

Kollet, O., Shivtiel, S., Chen, Y. Q., Suriawinata, J., Thung, S. N., Dabeva, M. D., Kahn, J., Spiegel, A., Dar, A., Samira, S., Goichberg, P., Kalinkovich, A., Arenzana-Seisdedos, F., Nagler, A., Hardan, I., Revel, M., Shafritz, D. A., \& Lapidot, T. (2003). HGF, SDF-1, and MMP-9 are involved in stress-induced human CD34+ stem cell recruitment to the liver. J Clin Invest, 112, 160-9. https://doi.org/10.1172/JCI17902

Kulbe, H., Thompson, R., Wilson, J. L., Robinson, S., Hagemann, T., Fatah, R., Gould, D., Ayhan, A., \& Balkwill, F. (2007). The inflammatory cytokine tumor necrosis factor-alpha generates an autocrine 
tumor-promoting network in epithelial ovarian cancer cells. Cancer Res, 67, 585-92. https://doi.org/10.1158/0008-5472.CAN-06-2941

Luo, L., Li, D. Q., Doshi, A., Farley, W., Corrales, R. M., \& Pflugfelder, S. C. (2004). Experimental dry eye stimulates production of inflammatory cytokines and MMP-9 and activates MAPK signaling pathways on the ocular surface. Invest Ophthalmol Vis Sci, 45, 4293-301. https://doi.org/10.1167/iovs.03-1145

Macfarlan, T. S., Gifford, W. D., Driscoll, S., Lettieri, K., Rowe, H. M., Bonanomi, D., Firth, A., Singer, O., Trono, D., \& Pfaff, S. L. (2012). Embryonic stem cell potency fluctuates with endogenous retrovirus activity. Nature, 487, 57-63. https://doi.org/10.1038/nature11244

Makino, S., Fukuda, K., Miyoshi, S., Konishi, F., Kodama, H., Pan, J., Sano, M., Takahashi, T., Hori, S., Abe, H., Hata, J., Umezawa, A., \& Ogawa, S. (1999). Cardiomyocytes can be generated from marrow stromal cells in vitro. J Clin Invest, 103, 697-705. https://doi.org/10.1172/JCI5298

Meriane, M., Duhamel, S., Lejeune, L., Galipeau, J., \& Annabi, B. (2006). Cooperation of matrix metalloproteinases with the RhoA/Rho kinase and mitogen-activated protein kinase kinase-1/extracellular signal-regulated kinase signaling pathways is required for the sphingosine-1-phosphate-induced mobilization of marrow-derived stromal cells. Stem Cells, 24, 2557-65. https://doi.org/10.1634/stemcells.2006-0209

Nakagawa, M., \& Yamanaka, S. (2010). Reprogramming of somatic cells to pluripotency. Adv Exp Med Biol, 695, 215-24. https://doi.org/10.1007/978-1-4419-7037-4_14

Nombela-Arrieta, C., Ritz, J., \& Silberstein, L. E. (2011). The elusive nature and function of mesenchymal stem cells. Nat Rev Mol Cell Biol, 12, 126-31. https://doi.org/10.1038/nrm3049

Perry, B. C., Zhou, D., Wu, X., Yang, F. C., Byers, M. A., Chu, T. M., Hockema, J. J., Woods, E. J., \& Goebel, W. S. (2008). Collection, cryopreservation, and characterization of human dental pulp-derived mesenchymal stem cells for banking and clinical use. Tissue Eng Part C Methods, 14, 149-56. https://doi.org/10.1089/ten.tec.2008.0031

Rojas, M., Xu, J., Woods, C. R., Mora, A. L., Spears, W., Roman, J., \& Brigham, K. L. (2005). Bone marrow-derived mesenchymal stem cells in repair of the injured lung. Am J Respir Cell Mol Biol, 33, 145-52. https://doi.org/10.1165/rcmb.2004-0330OC

Sordi, V., Malosio, M. L., Marchesi, F., Mercalli, A., Melzi, R., Giordano, T., Belmonte, N., Ferrari, G., Leone, B. E., Bertuzzi, F., Zerbini, G., Allavena, P., Bonifacio, E., \& Piemonti, L. (2005). Bone marrow mesenchymal stem cells express a restricted set of functionally active chemokine receptors capable of promoting migration to pancreatic islets. Blood, 106, 419-27. https://doi.org/10.1182/blood-2004-09-3507

Tikhonov, I., Doroshenko, T., Chaly, Y., Smolnikova, V., Pauza, C. D., \& Voitenok, N. (2001). Down-regulation of $\mathrm{CXCR}_{1}$ and $\mathrm{CXCR}_{2}$ expression on human neutrophils upon activation of whole blood by $\mathrm{S}$. aureus is mediated by TNF-a. Clinical and Experimental Immunology, 125, 414 \pm 422 . https://doi.org/10.1046/j.1365-2249.2001.01626.x

Tsai, L. K., Wang, Z., Munasinghe, J., Leng, Y., Leeds, P., \& Chuang, D. M. (2011). Mesenchymal stem cells primed with valproate and lithium robustly migrate to infarcted regions and facilitate recovery in a stroke model. Stroke, 42, 2932-9. https://doi.org/10.1161/STROKEAHA.110.612788

Ullah, I., Subbarao, R. B., \& Rho, G. J. (2015). Human mesenchymal stem cells - current trends and future prospective. Biosci Rep, 35, e00191. https://doi.org/10.1042/BSR20150025

Wynn, R. F., Hart, C. A., Corradi-Perini, C., O'neill, L., Evans, C. A., Wraith, J. E., Fairbairn, L. J., \& Bellantuono, I. (2004). A small proportion of mesenchymal stem cells strongly expresses functionally active CXCR4 receptor capable of promoting migration to bone marrow. Blood, 104, 2643-5. https://doi.org/10.1182/blood-2004-02-0526

Yorsangsukkamol, J., Chaiprasert, A., Palaga, T., Prammananan, T., Faksri, K., Palittapongarnpim, P., \& Prayoonwiwat, N. (2011). Apoptosis, production of MMP9, VEGF, TNF-alpha and intracellular growth of M. tuberculosis for different genotypes and different pks5/1 genes. Asian Pac J Allergy Immunol, 29, $240-51$.

Zhao, T., Zhang, Z. N., Rong, Z., \& Xu, Y. (2011). Immunogenicity of induced pluripotent stem cells. Nature, 474, 212-5. https://doi.org/10.1038/nature10135 
Zhao, Y., Xiao, A., Dipierro, C. G., Carpenter, J. E., Abdel-Fattah, R., Redpath, G. T., Lopes, M. B., \& Hussaini, I. M. (2010). An extensive invasive intracranial human glioblastoma xenograft model: Role of high level matrix metalloproteinase 9. Am J Pathol, 176, 3032-49. Ben DD, Reznick AZ, Srouji S, Livne E: Exposure to pro-inflammatory cytokines upregulates MMP-9 synthesis by mesenchymal stem cells-derived osteoprogenitors. Histochem Cell Biol., 129, 589-597. https://doi.org/10.1007/s00418-008-0391-1

Zhong, W., Tong, Y. P., Li, Y., Yuan, J. H., Hu, S. P., Hu, T. H., \& Song, G. (n. d.). Cancer Research Center, Medical College of Xiamen University. Xiamen, China; Department of General Surgery, The Affiliated Southeast Hospital of Xiamen University. Zhangzhou, China.

\section{Copyrights}

Copyright for this article is retained by the author(s), with first publication rights granted to the journal.

This is an open-access article distributed under the terms and conditions of the Creative Commons Attribution license (http://creativecommons.org/licenses/by/4.0/). 